\title{
Diversity of Gastropods in the Selected Rivers and Lakes in Bukidnon
}

\author{
Gloria L. Galan, Marilou M. Ediza, Marife S. Servasques, and Heidi C. Porquis
}

\begin{abstract}
Diversity and abundance of Gastropods were determined in seven sampling sites in Bukidnon, Philippines: Maapag, Matay, and Tigua rivers and Lakes Napalit, Apo, and Pulangui for a period of one year from June 2011-May 2012. Pulangui Lake is a manmade impoundment while all the other sites are natural formations. Sampling was done in a $100 \mathrm{~m} \times$ $3 \mathrm{~m}$ belt transect and gastropods were collected within the belt transect by hand picking and sieving. Seven species representing 5 families were collected. Shannon-Weiner index shows that the highest diversity is in Tigua river $\left(H^{\prime}=0.518\right)$ and lowest is in Pulangui lake $\left(H^{\prime}=0.144\right)$. Tigua River has also the most abundant gastropod species.
\end{abstract}

Index Terms-Diversity, gastropods, lakes, rivers, Philippines.

\section{RATIONALE}

Gastropods are single-valve, soft-bodied class of animals in phylum Mollusca.

It is the largest, extremely diverse taxa that includes over 40, 000 species of which 5,000 are fresh water snails found in wetlands like lakes, ponds and streams worldwide [1]. Snails, slugs, and limpets, either marine, fresh water or terrestrial belong to this class. Also included in it are the pulmonates and some prosobranch [2].

Bukidnon is one of the provinces in Mindanao endowed abundantly with rivers, lakes and other water impoundments. These bodies of water are significant resources that meet the daily protein dietary needs of the communities living nearby. This protein need is supplied in part by the gastropods or snails gleaned by fisher folks and cooked at home. Some also harvest the gastropods to augment livelihood by marketing or processing them into feeds of poultry and aquaculture. The Melanoides spp., Thiara granifera and Vivipara costata are the species usually harvested and cooked with coconut milk. For Pomacea canaliculata some reports indicate that the species is cooked as escargot in urban areas in the Philippines and abroad.

Gastropods are also good water quality indicators and the abundance of some species may reveal the current status of

Manuscript received June 12, 2014; revised October 18, 2014. This research entitled "Shell Band Pattern of Golden Apple Snail (Pomacea cancaliculata, Lamarck) in Selected Aquatic Habitats" was funded by Central Mindanao University, Bukidnon, Philippines for the period of June 2010-February 2011.

The authors are with the Biology Department, Central Mindanao University, 8710, Musuan, Bukidnon, Philippines (e-mail: glorialg2008@yahoo.com.ph). any water impoundment. In Bukidnon, Philippines, the wetlands in addition to their basic ecological functions, also serve as source of water for irrigation and domestic consumption, as laundry sites and bathing places not only of people but also for domestic animals like carabaos (water buffalo); as duck rearing areas in the rural communities as well as local tourist and recreation spots. Along with these activities, there is also quarrying particularly in in Pulangui Lake and Tigua River. Compounded by the unpredictable climate change these activities may have adverse impact on species diversity specifically on gastropod fauna of these wetlands. This habitat loss or degradation together with the introduction of exotic species as well as the unsustainable use of water resources are the identified threats to many of the sensitive wetland wildlife [3], [4]. This survey could thus provide part of the baseline data that might be useful for future use.

\section{METhODOLOGY}

Entry protocol was observed after which quarterly samplings were done in 4 selected rivers and 3 lakes in Bukidnon from June 2011-May 2012 with a sampling effort of 8 hours per sampling site. These sites were given specific sampling designations. Also, these sites except for Tigua and Matay rivers are in close proximity to agricultural lands or human settlements.

\section{A. Sampling Site 1: Tigua River}

The river is found in barangay Comawas, San Fernando, Bukidnon. This is a large river, with shallow and deep portions and variable current flow. Small pebbles and stones form part of its muddy clayish bed. Grasses and weeds line the river bank. Taro plants were also seen.

\section{B. Sampling Site 2: Maapag River}

This is considered as the biggest river of the barangay and serves as the primary source of water for the crops. Grasses, herbs and trees line the deep river bank. The river bed is also muddy.

\section{Sampling Site 3: Pulangui Lake}

Pulangui Lake has a wide range of area with turbid water, muddy to clayish substrate and surrounded by trees, shrubs, grasses and macrophytes. It is known for fishing, bathing and laundry area among the nearby communities, some of its islets are used as grazing spots and some as agricultural land.

The sampling site was established along the bank of Barangay Panadtalan, Maramag, Bukidnon. Trees, shrubs and grasses were submerged in the water due to the high level of water during the sampling trip. 


\section{Sampling Site 4: Sawaga River}

The sampling site established for the Sawaga River bank was in Barangay Kalasungay, Malaybalay City. Big stones and boulders line the river bank and bed, though some pebbles were also observed. The sides are lined with tall grasses and shrubs.

\section{E. Sampling Site 5: Lake Apo}

Lake Apo is considered as a deep lake. The bank is lined with trees, shrubs, grasses and some macrophytes. A privately owned tourist inn occupies a portion of the shoreline. Some households were also seen nearby. Substrate was also muddy.

\section{F. Sampling Site 6: Napalit Lake}

Napalit Lake is in Pigtauranan, Pangantucan, Bukidnon. The lake bank is also lined with trees, shrubs, grasses and macrophytes with muddy substrate. However, a little farther from the shoreline landward were sugarcane and root crops plantations and cornfields. There are also few households nearby on one side of the lake. The lake is a favorite spot for anthropogenic activities like bathing, washing of clothes and wallowing pond for carabaos (water buffalo).

\section{G. Sampling Site 7: Matay River}

Matay River is in Mabuhay, San Fernando, Bukidnon. It is a narrow river with rocky to sandy substrate and the bank is lined with grasses.

Three belt transects $(100 \mathrm{~m} \times 3 \mathrm{~m})$ were set in suitable areas in these sampling sites. Gastropods collected were subsequently processed for proper identification. Data were analyzed in the BIOPRO software to get alpha and beta type of diversity indices which were useful in evaluating diversity within individual sampling units as well as measuring how diversity differs among the study areas. Richness and evenness of gastropod species were also obtained.

The physico-chemical parameters determined were temperature, water depth, and $\mathrm{pH}$.

\section{RESULTS AND DISCUSSION}

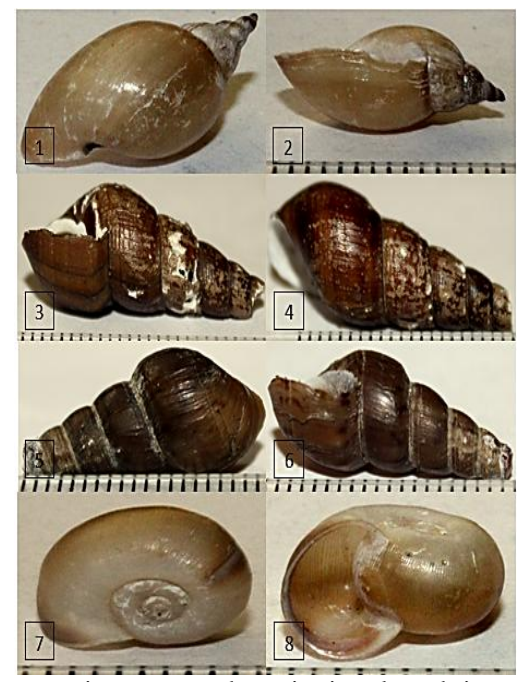

Fig. 1. Representative gastropod species in selected rivers and lakes in Bukidnon1-2. Lymnaea natalensis 3-4. Melaniodes tuberculata 5-6. Melaniodes turriculus 7-8. Planorbis $\mathrm{sp}$.
Seven gastropod species were collected from the different sites: P. canaliculata, Vivipara costata, Lymnaea natalensis, Melanoides tuberculata, Melanoides turricula, Thiara granifera and Planorbis sp. (Table I, Fig. 1, Fig. 2). These represent 5 families: Ampullariidae, Viviparidae, Lymnaeidae and Planorbidae, and 6 genera: Pomacea, Lymneae, Melanoides, Thiara and Planorbis. Among the species, $P$. canaliculata was always most abundant and occurred in all sampling sites.

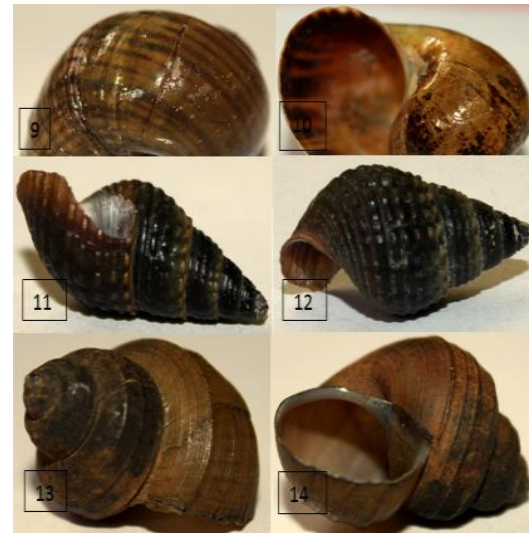

Fig. 2. Representative gastropod species in selected rivers and lakes in Bukidnon 9-10. Pomacea canaliculata 11-12. Thiara granifera 13-14. Vivipara costata.

TABLE I: CLASSIFICATION OF GASTROPODS COLLECTED IN SEVEN SELECTED SITES IN BUKIDNON FROM JUNE 2011-MAY 2012

\begin{tabular}{|l|l|l|l|}
\hline \multicolumn{1}{|c|}{ FAMILY } & GENUS & \multicolumn{1}{|c|}{ SPECIES } & \multicolumn{1}{c|}{$\begin{array}{c}\text { COMMN } \\
\text { NAME }\end{array}$} \\
\hline Ampullariidae & Pomacea & $\begin{array}{l}\text { Pomacea } \\
\text { canaliculata }\end{array}$ & $\begin{array}{l}\text { Kuhol/ Golden } \\
\text { Apple Snail }\end{array}$ \\
\hline Viviparidae & Vivipara & $\begin{array}{l}\text { Vivipara } \\
\text { costata }\end{array}$ & Kuhol/ege \\
\hline Lymnaeidae & Lymnaea & $\begin{array}{l}\text { Lymnaea } \\
\text { natalensis }\end{array}$ & Crib Physa \\
\hline Thiariidae & Melanoides & $\begin{array}{l}\text { Melanoides } \\
\text { tuberculata }\end{array}$ & $\begin{array}{l}\text { Suso/Red- } \\
\text { rimmed } \\
\text { Melania }\end{array}$ \\
\cline { 2 - 4 } & Thiara & $\begin{array}{l}\text { Melanoides } \\
\text { turricula }\end{array}$ & $\begin{array}{l}\text { Suso/Fawn } \\
\text { Melania }\end{array}$ \\
\cline { 2 - 4 } & Pranifera & $\begin{array}{l}\text { Suso/Quilted } \\
\text { Melania }\end{array}$ \\
\hline Planorbidae & Planorbis & Planorbis sp. & Rams horn \\
\hline
\end{tabular}

The peak of the species accumulation curve (Fig. 3) was attained in Tigua, Matay rivers as well as Lake Apo in this study.

Gastropod abundance (Tables II, III and Fig. 4) was highest in Tigua river with 638 individuals (6 species), followed by Matay River with 600 individuals (4 species), Lake Apo with 276 individuals (4 species), Pulangui Lake with 160 individuals (2 species), Maapag River with 100 individuals ( 2 species), Napalit Lake with 76 individuals (2 species) and Sawaga River with 36 individuals (3 species). Moreover, among the species, P.canaliculata appears to be most widely distributed among the sampling sites confirming earlier observation on the invasive nature of the species [4], [5]. Melanoides tuberculata and Thiara granifera and Planorbis sp. appear only in the lotic sampling site and not in the lakes. The occurrence of Melanoides tuberculata in this type of habitat was similarly noted in literature [6].

Shannon-Weiner index of diversity (Fig. 5 and Table IV) 
is also highest in Tigua River $\left(H^{\prime}=0.518\right)$, followed by Sawaga River $\left(H^{\prime}=0.426\right)$, Lake Apo $\left(H^{\prime}=0.41\right)$, Matay
River $\left(H^{\prime}=0.361\right)$, Maapag River $\left(H^{\prime}=0.292\right)$, Napalit Lake $\left(H^{\prime}=0.291\right)$ and the lowest was Pulangui Lake $\left(H^{\prime}=0.141\right)$.

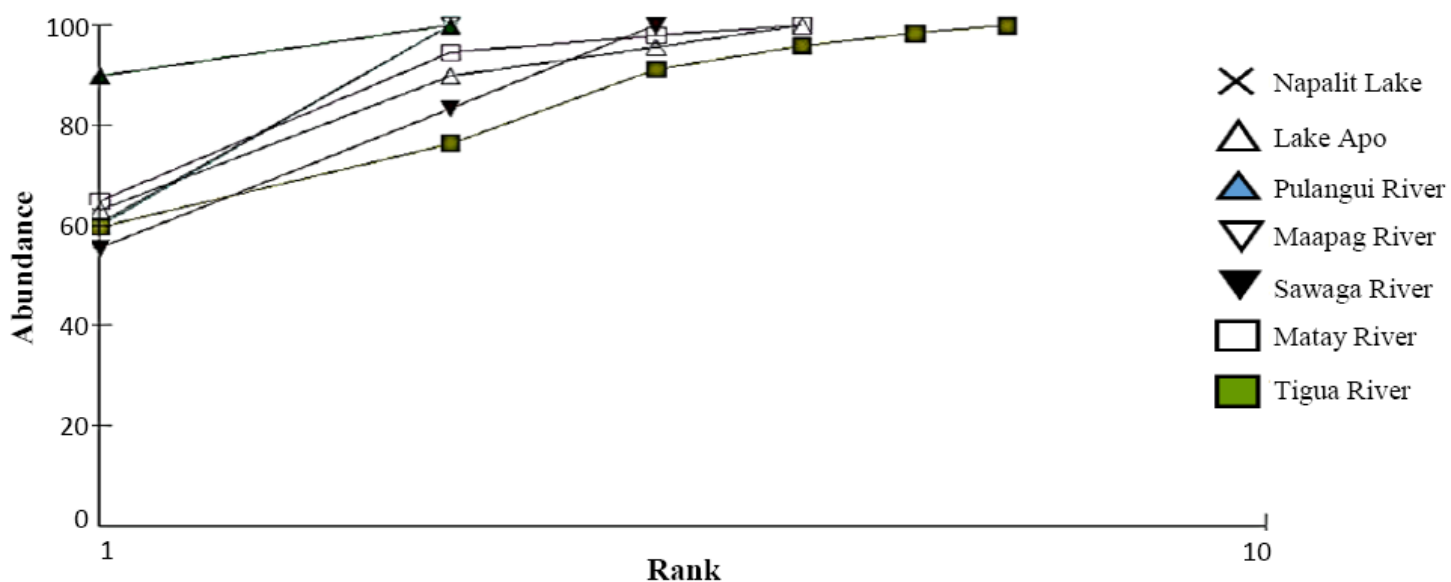

Fig. 3. Species accumulation curve of gastropods in seven selected sampling sites in Bukidnon.

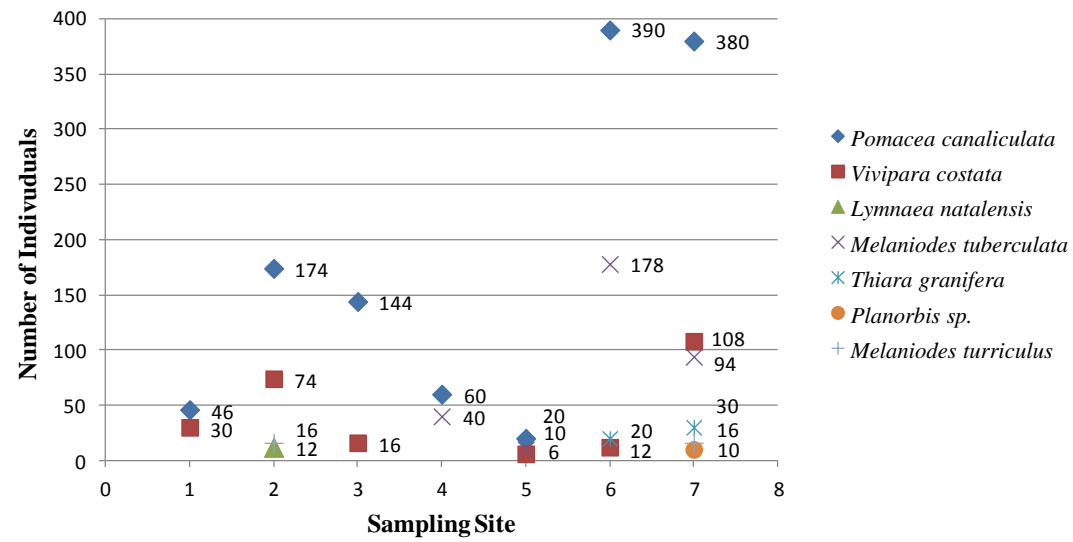

Fig. 4. Graph analysis of gastropod occurrence in different sampling sites.

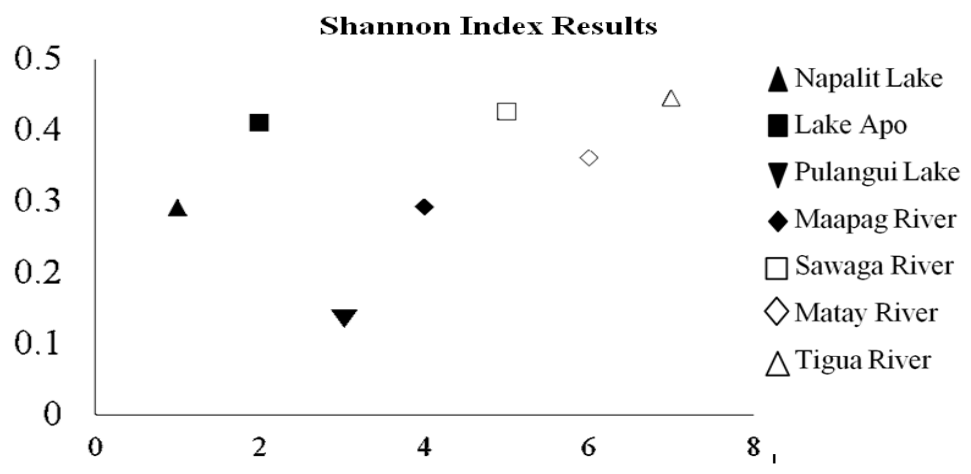

Fig. 5. Shannon-Weiner index plot of gastropods in seven selected sampling sites in Bukidnon.

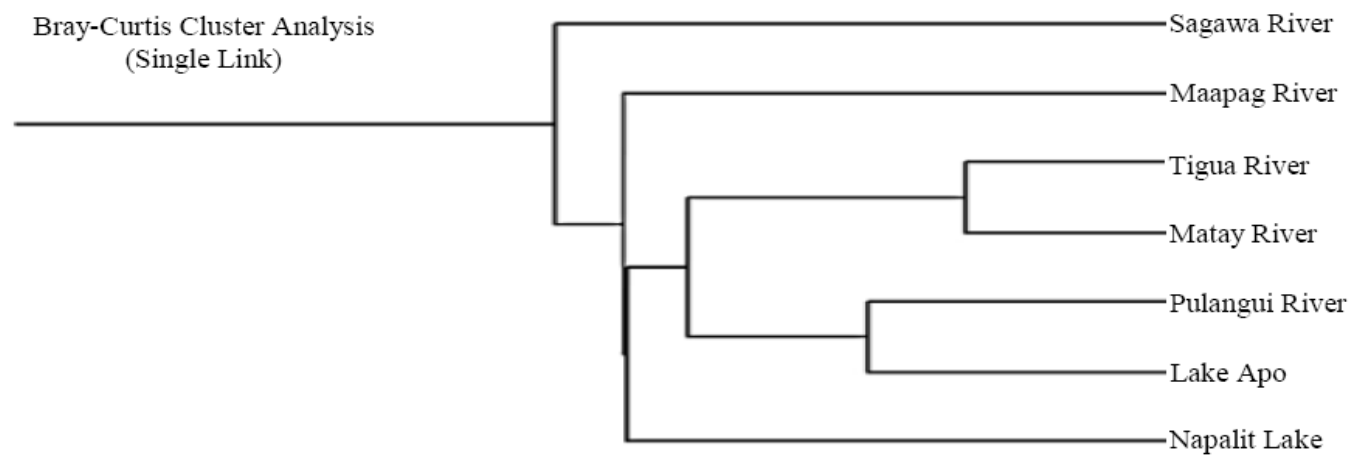

0. \% Similarity $50 . \quad 100$

Fig. 6. Dendogram of species composition of gastropods in seven selected sampling sites in Bukidnon. 
TABLE II: TOTAL NUMBER OF INDIVIDUALS OF GASTROPOD SPECIES IN SELECTED SAMPLING SiteS IN BUKIDNON

\begin{tabular}{|c|c|c|c|c|c|c|c|c|}
\hline \multicolumn{9}{|c|}{ Sampling Area } \\
\hline Species & Napalit Lake & Lake Apo & Pulangui Lake & Maapag River & Sawaga River & $\begin{array}{l}\text { Matay } \\
\text { River }\end{array}$ & $\begin{array}{l}\text { Tigua } \\
\text { River }\end{array}$ & Total \\
\hline $\begin{array}{l}\text { Pomacea } \\
\text { canaliculata }\end{array}$ & 46 & 174 & 144 & 60 & 20 & 390 & 380 & 1214 \\
\hline Vivipara costata & 30 & 74 & 16 & & 6 & 12 & 108 & 246 \\
\hline $\begin{array}{l}\text { Lymnaea } \\
\text { natalensis }\end{array}$ & & 12 & & & & & & 12 \\
\hline $\begin{array}{l}\text { Melaniodes } \\
\text { tuberculata }\end{array}$ & & & & 40 & 10 & 178 & 94 & 322 \\
\hline Thiara granifera & & & & & & 20 & 30 & 50 \\
\hline Planorbis sp. & & & & & & & 10 & 10 \\
\hline $\begin{array}{l}\text { Melaniodes } \\
\text { turiculus }\end{array}$ & & 16 & & & & & 16 & 32 \\
\hline Total & 76 & 276 & 160 & 100 & 36 & 600 & 638 & 1886 \\
\hline
\end{tabular}

Bray-Curtis cluster analysis (Fig. 6) shows three unique clusters of habitat: Cluster 1-Sawaga river, Cluster 2Maapag River, Cluster 3-Tigua River, Matay River, Pulangui Lake and Lake Apo. Sawaga River appears to be the most unique habitat of all sampling sites. This is probably due to its substrate. Sawaga River has more boulder rocks and less soil substrate and grasses along the bank that could serve as favourable habitat to gastropods.

High species diversity in Tigua River is probably attributed to its location and substrate. Its muddy clay substrate could be favourable for burrows as snails crawl to escape from possible predators like crustaceans, leeches, fishes, ducks and birds. The riverbank of Tigua River is likewise lined with grasses and weeds which serve as depository of egg masses and food. The submerged rocks and pebbles in the shallower water are favourable for the accumulation freshwater algae which is food to these grazers. The substrate is also a possible hibernating place during dry seasons. On top of these, Tigua River cuts through the highlands of San Fernando, Bukidnon where agricultural activities are not yet intensive. However, the occurrence of $P$. canaliculata in the site may signify a probable threat to the other extant species in the area.

TABLE III: SUMMARY OF GASTROPOD MEAN DATA AND TOTAL INDIVIDUAL IN SEVEN SELECTED SAMPLING SITES IN BUKIDNON

\begin{tabular}{|l|c|c|c|}
\hline \multicolumn{1}{|c|}{ Sample } & $\begin{array}{c}\text { Mean } \\
\text { Individuals }\end{array}$ & $\begin{array}{c}\text { Total } \\
\text { Individuals }\end{array}$ & $\begin{array}{c}\text { Total } \\
\text { Species }\end{array}$ \\
\hline Napalit lake & 10.857 & 76 & 2 \\
\hline Lake apo & 39.429 & 276 & 4 \\
\hline Pulangui lake & 22.857 & 160 & 2 \\
\hline Maapag river & 14.286 & 100 & 2 \\
\hline Sawaga river & 5.143 & 36 & 3 \\
\hline Matay river & 85.714 & 600 & 4 \\
\hline Tigua river & 91.143 & 638 & 6 \\
\hline
\end{tabular}

TABLE IV: SHANNON-WEINER INDEX FOR GASTROPODS IN SEVEN SELECTED SITES IN BUKIDNON

\begin{tabular}{|l|l|l|l|l|l|l|l|}
\hline Index & Napalit Lake & Lake Apo & Pulangui Lake & Maapag River & Sawaga River & Matay River & Tigua River \\
\hline Shannon H' Log Base 10. & 0.291 & 0.41 & 0.141 & 0.292 & 0.426 & 0.361 \\
\hline Shannon Hmax Log Base 10. & 0.301 & 0.602 & 0.301 & 0.301 & 0.477 & 0.602 \\
\hline Shannon J' & 0.968 & 0.682 & 0.469 & 0.971 & 0.778 \\
\hline
\end{tabular}

\section{CONCLUSION}

This study shows the apparent dominance of the introduced and invasive species $P$. canaliculata in sampled wetlands. The results further indicate that gastropod diversity in the wetlands of Bukidnon's highlands are vulnerable to the species.

\section{RECOMMENDATION}

It is recommended therefore that monitoring activities should be done.

\section{ACKNOWLEDGEMENT}

The authors want to extend their heartfelt gratitude to Central Mindanao University for the grant of financial support for the whole duration of the research. To all the people who contributed their time and effort in collection and sampling activities.

\section{REFERENCES}

[1] R. T. Abbott, "Snail invaders," Natural History, vol. 59, no. 2, pp. 80$85,1950$.
[2] F. G. Thompson. (1984). Field guide to the freshwater snails of Florida. Florida Museum of Natural History. [Online]. pp. 6-7. Available: https://www.flmnh.ufl.edu/malacology/fl-snail/snails1.htm

[3] E. E. Strong, O. Gargominy, W. F. Ponder, and P. Bouchet. (2008). Global diversity of gastr.pods (Gastropoda: Mollusca) in freshwater. [Online]. 149-166. pp. Available: http://www.bioone.org./doi/abs/10.1899/0706/.1? journalcode. Jabs

[4] R. H. Cowie, "Shell pattern polymorphism in a 13-year study of the land snail Theba pisana (Muller) (Pulmonata: Helicidae)," Malacologia, vol. 34, pp. 1-2, pp. 87-97, 1992.

[5] G. L. Galan, "Snails and mussels in Musuan, Bukidnon," Technical Report, Central Mindanao University. 1996.

[6] A. Giovanelli, C. L. P. A. C. D. Silva, G. B. E. Leal, and D. F. Baptista, "Habitat preference of freshwater snails in relation to environmental factors and the presence of the competitor snail Melanoides tuberculatus (Müller, 1774)," Mem. Inst. Oswaldo Cruz., Rio de Janeiro, vol. 100, no. 2, pp. 169-176, April 2005.

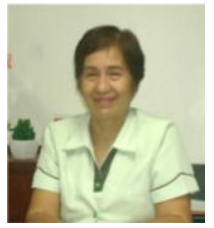

Gloria L. Galan was born in Nueva Estrella, Socorro, Surigao del Norte on November 5, 1952. She finished her bachelor degree of science in biology at the University of San Carlos, Cebu City, Philippines on May, 1974 and M.S. degree in biology in June 2013 at Central Mindanao University, Musuan, Bukidnon, Philippines. She has been teaching both the basic and major biology courses particularly invertebrate zoology, zoogeography, phycology, and comparative vertebrate anatomy at Central Mindanao University since July 1976. She was trained as an aquaculturist in 1991 (Tilapia and Catfish Culture and Hatchery) but later interest had been 
glared towards malacology. She had done researches and training on the culture and identification of freshwater and identification of freshwater and marine molluscs.

She is a member of some organizations like: Philippine Society of Biochemistry and Molecular Biology (PSBMB); Philippine Association of Institution for Research (PAIR); Asian Conference of Academic Journal and Higher Education Research (IAMURE); Philippine Society for the Advancement of Genetics, Inc. (PhilSAGen); Biology Teachers' Association (BIOTA); Malacological Society of the Philippines (MSPLifetime Member) and University Alumni Association at Central Mindanao University Faculty Association, Inc. (CMUFAI).

Recently, she is the project leader of the research on "Assessment diversity an management initiatives on molluscan fauna in Bucas Grande Island, Surigao del Norte, Philippines and study leader on "Molluscs in Bucas Grande Island, Surigao del Norte".

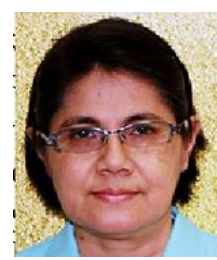

Heidi C. Porquis was born on November 26, 1954 in Bonifacio Misamis Occidental, Philippines. She holds a bachelor of science degree from Silliman University, Dumaguete City, and a master degree of science in biology from Central Mindanao University, Bukidnon, Philippines.

She is currently serving in the Faculty of the Biology Department to teach basic and major courses in biology particularly genetics, ecology, microtechnique and radiation biology. In addition to teaching, she is also assigned to the research and extension activities of the department. She is currently involved in two research projects one on drug discovery (The Tuklas Lunas) and the other on assessment of Molluscan fauna in Bucas Grande Island as a study leader and collaborator respectively. She has also presented scientific posters in local, national and international conferences, and co-authored instructional materials used in the Biology Department.

She is a member of the Biology Teachers' Association (BIOTA) of the Philippines, Malacological Society of the Philippines, the Wildlife Conservation Society of the Philippines (WCSP), the PhilSAGen, the Silliman University Alumni Association, the Central Mindanao University Alumni Association and the Central Mindanao University Faculty Association, Inc.

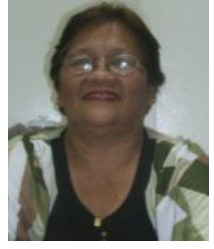

Marilou M. Ediza was born in Dapa, Surigao de Norte, Philippines on August 1, 1952. She finished her master degree of science in aquaculture in April 2003 at Mindanao State University, School of Marine Fisheries and Technology, Naawan, Misamis Oriental, Philippines.

Presently, she is working in Central Mindanao University, Musuan, Bukidnon, Philippines as an assistant professor of the Department of Biology. She teaches botany, ecology, and principles of fishery science. Her research interest includes bangus (Milkfish) and shrimp culture in ponds and cages as well as ecological research in aquatic environments.

Professor Marilou M. Ediza is a member of BIOTA (Biology Teacher's Association of the Philippines) - Bukidnon Chapter, Philippine Society for Biochemistry and Molecular Biology, Philippine Association of Institutions for Research, Inc. and CMUFA (Central Mindanao University Faculty Association).

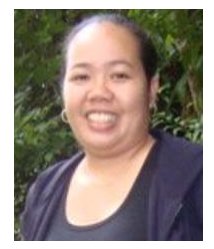

Marife S. Servasques was born on August 10, 1977 in Taganaan, Surigao del Norte, Philippines. She got her bachelor degree of science in forestry at Central Mindanao University, Philippines in 2003. She is a malacology enthusiast and worked as a research assistant in this project name "Diversity of Gastropods in the Selected Rivers and Lakes in Bukidnon". She had done training in the culture and identification of freshwater and marine gastropods. 